\title{
Vory: den ryska supermaffian
}

\author{
Mark Galeotti (översatt av Manne Svensson) \\ Stockholm: Albert Bonniers Förlag 2019 \\ 352 sidor. ISBN 9789100178413
}

Recenserad av Mi Lennhag [doktorand, Statsvetenskapliga institutionen, Lunds universitet, mi.lennhag@svet.lu.se]

Begreppet maffia används om kriminella nätverk av olika slag världen över. En rysk gruppering kallad vory v zakone - vilket kan översätts som "tjuvar i lagen» - har djupa rötter både historiskt, kulturellt och politiskt. Enligt Mark Galeotti är ryska vory inget nytt fenomen, utan bör förstås mot bakgrund av kriminella ligor under tsartid, bolsjevik-styre, revolutioner, krig och svält.

Galeotti har ägnat flera år åt fältstudier, forskning och expertuppdrag om vory. Detta är viktig, komplicerad och troligen bitvis farlig forskning. Boken ger en historisk översikt av rysk brottslighet och hur den sammanvävts med samhällskulturen. Galeotti menar att den kriminella sfären varit och är nära sammanlänkad med både den sovjetiska och ryska staten.

Att undersöka informella nätverk och parallella samhällssystem är avgörande för förståelsen av exempelvis Rysslands omfattande och djupt rotade korruption, oligarkernas makt och den utbredda bristande tilliten för staten. Enligt mig överlevde sovjetsystemet längre "tack vare» de informella system som sovjetapparaten genererade - för varudistribution och tillgång till myndighetsdokument, bostäder och livsviktiga tjänster. Det officiella var beroende av det inofficiella. Ryssar talar ibland om välkända hemligheter när de beskriver Sovjettidens samhällsdistribution.

Galeotti beskriver hur det under tidigt 1900-tal, främst i arbets- och straffläger, etablerades en alltmer unik kultur och strikt uppförandekodex som inte tillät samarbete med stat eller rättsväsende. Ritualer, uttryck och utmärkande tatueringar verkade sammansvetsande. En vor v zakone följde inte officiella lagar - som alltså inte erkändes i dessa grupper - utan upprätthöll egna koder, regler samt heder.

Sovjetunionen och Ryssland har länge haft en relativt stor befolkningsandel i fängelser och arbetsläger, särskilt under Gulag-eran. Fängelsemiljön var hård, hierarkisk, våldsam och förstärkte en existerande machokultur. Efter andra världskriget och amnestin efter Stalins död 1953 släpptes plötsligt miljoner fångar fria, främst yrkeskriminella. Och utanför fängelserna fanns krigsveteraner och unga män med bistra framtidsutsikter. Brottsligheten ökade och kriminella nätverk växte i storlek 
och styrka. Mycket av fängelseerfarenheterna letade sig in i vardagligt språk, jargong, myter, kultur och syn på maskulinitet och heder.

Under perestrojkaåren blev vory en länk mellan vanligt folk och eftertraktade bristvaror, via svarta marknaden eller direkt från fabriker. Vid det laget hade vory uppnått struktur, auktoritet och "respekt» genom sina distributionskanaler, samt bitvis rollen som informella ledare.

När sovjetsystemet kollapsade uppstod luckor i samhället, som Galeotti menar delvis fylldes av maffian. Det turbulenta ryska 90-talet innehöll ekonomiskt kaos, svåröverskådliga privatiseringar och affärsmän som skapade enorma förmögenhetermen också bomber, mord, prickskyttar och rivaliserande grupper på öppen gata. Handeln med narkotika, piratkopior och människor tilltog. Polisen var relativt svag, domstolsväsendet inte uppbyggt, lagstiftning kring äganderätt var diffus för både medborgare och småföretag. Partiet föll, men någon ny stat etablerades inte fullt ut i dess ställe. För många ryssar var det som att vara utan stat helt och hållet. Galeotti menar att den relativt egalitära vory-kulturen inte tolererade 90 -talets ledargestalter som påminde om italiensk maffia, varvid ännu fler skjutningar skedde.

Galeotti beskriver skickligt 1900-talets laglöshet, oförutsägbarhet, oväntade vändningar och vakuum, vilket skapar förståelse för hur ryska kriminella nätverk kunnat styra så länge och i sådan omfattning.

Den ryska fängelsekulturen blev en del av samhället. Näringslivet påverkades av maffians beskyddarverksamhet. Människor fick tilltro till informella system. Symbiosen fortsätter, enligt Galeotti. Galeotti ser dagens system som en miljö där organiserad brottslighet lätt frodas, med nära band till staten. Legal och illegal makt flyter ihop. De kriminella nätverken har följt med in i den digitala eran och skickligt anpassat sig till samtiden.

Putins löften om lag och ordning blev i stället en diffus överenskommelse med de kriminella. Makten krävde viss lojalitet och en del av vinsten, medan kriminella nätverk kunde fortsätta operera. Det öppna gatuvåldet minskade, men den organiserade brottsligheten blev som en ny öppen hemlighet i det nya Ryssland. I det sammanhanget skulle jag gärna ha sett tydligare resonemang kring varför KGB och FSB faktiskt inte utrotat de kriminella nätverken.

Galeotti ser den ryska maffian eller postsovjetiska kriminaliteten som en icke-hierarkisk och postmodern organisation - ett nätverk där grupper samarbetar när det gynnar dem. Nätverken kan ägna sig åt både illegala och legala affärer. Den ryska brottsligheten är heller inte nödvändigtvis "rysk», utan inkluderar även exempelvis en stor andel georgier.

Om det uppstår ett folkligt önskemål om något "förbjudet» - även något så trivialt som ost under pågående sanktioner mot Ryssland 2014 - så uppstår en svart marknad, och en sådan marknad finns det grupper som vill kontrollera. Dagens ryska stat kan sägas underlätta för och tolerera viss kriminalitet.

Galeotti skildrar skickligt sin bild av hur dagens Ryssland präglats av sin symbios med den undre världen. Kriminalitet och stat kan vara oskiljaktiga. Mer statistik och hårda fakta kring vorys makt hade dock ökat förståelsen ännu mer. 
Boken visar vikten av att känna historien för att förstå nutiden. Boken skapar samtidigt bättre förståelse för vad Ryssland kan bli i framtiden, efter Putin, eftersom gangsters är involverade i både politik och ekonomi, men även används som agenter i Putins krig mot väst. Rysk organiserad brottslighet mobiliseras som ett verktyg i dagens ryska geopolitik, menar Galeotti.

Galeotti lyckas även "avmystifiera» maffian på ett önskvärt sätt genom beskrivningar av struktur och arbetsmetoder. Att vi i dagens filmer och tv-serier allt oftare ser ryska kriminella nätverk - snarare än ryska spioner - som kan sätta uppdragsgivare i kontakt med förbjudna varor och illegala tjänster med affärsmässig effektivitet, antyder att Galeotti beskriver ett samhällsfenomen vi verkligen behöver förstå. 